\title{
アモルファス半導体とその応用
}

\author{
羽山昌宏*, 山崎照彦* \\ * 三菱電機株式会社材料研究所
}

\section{Amorphous Semiconductors and their Application to Electronic Devices}

\author{
Masahiro Hayama* and Teruhiko Yamazaki* \\ * Materials \& Electronic Devices Laboratory, Mitsubishi Electric Corporation
}

\begin{abstract}
As amorphous materials are characterized by atomic disorder, amorphous semiconductors have unique electrical and optical properties such as localized states, mobility edges, states in the gap arising from structural defects, variable-range hopping conduction, and optical absorption. The properties of amorphous semiconductors depend on the deposition method and its deposition conditions because amorphous materials are in non-equilibrium state. While deposition methods using neutral radical species are well known, methods using ion species are recently being considered. Since the discovery of bydrogenated amorphous silicon with structural sensitivity, a new and wide field from basic science to applications to large-area electronic devices has been opened. The basic properties, deposition methods and applications of amorphous semiconductors, particularly hydrogenated amorphous silicon are summarized.
\end{abstract}

Key words: amorphous material, amorphous semiconductor, hydrogenated amorphous silicon, thin film deposition method, amorphous electronic device

\section{1. はじめに}

よく知られているように固体物理学は Bragg 父子に よる結晶の発見以来, その格子の周期性といら基本的概 念に基づきその後の量子力学の発展と相まって大きな進 歩を遂げた。例宎ば, 金属, 半導体等の特徵を表す諸々 の物性に関し, それらを司る電子の運動は周期ポテンシ ャルを通じて運動量空間に和いてそのエネルギー準位を 㛜密に定めることができた。これによって様々の結晶の 物性が添ぼ完全に理解でき，なた新しい物質を生む原動 カともなり今日の華々しい電子工学の基礎を築いた。そ れに反し、アモルファスやガラス等一般に非晶質と呼ば れる物質の性質については, 格子の非周期性による数学 的取り扱いの困難さが非晶質物質に対する普遍的理解を 妨げた。この分野に和ける最も著しい成果は 1958 年 P. W. Anderson（1977 年に Mott と共にノーベル賞を 受賞）によって提唱されたランダムな系においてはその

* T661 尼崎市塚口本町 8 丁目 1-1 (1-1, TsukaguchiHonmachi 8-chome, Amagasaki, Hyogo, 661 Japan)

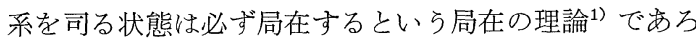
万。

アモルファス物質の中には, アモルファス半導体, ガ ラス,アモルファス合金, アモルファス磁性体等があり, 結晶にない特異な物性と応用を持っている2 价。アモル ファス半導体研究の起源は 1948 年のゼログラフィ技術 と結びついたアモルファス $\mathrm{Se}$ まで遡ることができるが, 「アモルファス半導体」といら用語が出てくるのは遅い。 といらのは, バンドギャップの概念が結晶による性質で あると考兄られたため,「アモルファス」と「半導体」と は相入れないと思われていたからである。アモルファス 半導体を意識した研究は 1955 年のカルコゲナイドガラ スの研究であるが, 1975 年に Spear と Le Comber ${ }^{7}$ が，価電子制御が可能である水素化アモルファスシリコ ン (hydrogenated amorphous silicon: a-Si:H) 膜を初

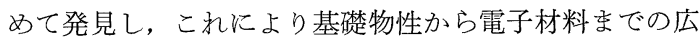
い新分野が出現した。基礎的には，バンドギャップ概念 の見直しや結晶系にない光学的・電気的性質を示した。 応用的には, 微視的構造や周辺構造に対し敏感すぎない 
という結晶にない構造柔軟性や光学的・電気的性質の可 変性が利用でき，広い応用分野を期待することができる ようになった。

アモルファス半導体材料としては, a-Si:H (バンドギ ヤップ〜 $1.7 \mathrm{eV})$ の発見後, バンドギャップの広い材料 $(\sim 2 \mathrm{eV})^{8)^{*}}$ としては, $\mathrm{a}-\mathrm{Si}_{1-x} \mathrm{C}_{x}: \mathrm{H}, \mathrm{a}-\mathrm{Si}_{1-x} \mathrm{~N}_{x}: \mathrm{H}$ や a$\mathrm{Si}_{1-x} \mathrm{O}_{x}: \mathrm{H}$ があり, バンドギャップの狭い材料 ( 1.5 $\mathrm{eV})^{9)}$ としては, $\mathrm{a}-\mathrm{Si}_{1-x} \mathrm{Ge}_{x}: \mathrm{H}$ や $\mathrm{a}-\mathrm{Si}_{1-x} \mathrm{Sn}_{x}: \mathrm{H}$ があ る。

アモルファス半導体の膜堆積法としては, 主としてラ ジカル種を用いる高周波プラズマ化学気相堆積法 (Radio Frequency Plasma Chemical Vapor Deposition: RFPCVD) などや主としてイオン種を用いる電子サイ クロトロン共鳴プラズマ化学気相堆積法 (Electron Cyclotron Resonance Plasma Chemical Vapor Deposition：ECRPCVD) ${ }^{10)}$ などがある。

\section{2. 基礎物 性 (2) 6)}

\section{1 非平衡状態と水素結合構造}

アモルファスは非平衡状態であり, 原子配置は一義的 に定まらず，格子の不規則性を持っている。その格子の 不規則性は長距離秩序はないが，短距離秩序は存在して いる。従って, 結晶シリュンは 4 つの結合手をもってい るが，アモルファスシリコンに掠いても同様に成立して いる。しかし，ランダムな 3 次元のネットワーク構造を とるアモルファスでは，この４配位の結合は強すぎるた め, シリコンの結合しない手，すなわち未結合手（ダン グリングボンド）を適度に生成した方が歪みエネルギー が小さくなる。水素を含まないアモルファスシリコン (a-Si) では $10^{19} \sim 10^{20} \mathrm{~cm}^{-3}$ 程度の高密度のダングリング ボンドが存在する。そのアモルファスシリコンのダング リングボンドに一価元素, 例党ば水素を終端した水素化 アモルファスシリコン $(\mathrm{a}-\mathrm{Si}: \mathrm{H})$ は, ダングリング ボ ンドを $10^{15} \sim 10^{18} \mathrm{~cm}^{-3}$ 程度著しく減少させることが できる。

$\mathrm{a}-\mathrm{Si}: \mathrm{H}$ 中のシリコンへの水素の結合構造抒よび組成 比は試料の作成条件や履歷によって決まるものであり, 構造欠陥, 電気的・光学的性質等に大きな影響を与兄 る。水素が関係した結合構造は, 結合した水素の振動に 関する情報が得られる赤外分光法 ${ }^{11)}$ に上り分析できる。 図 1 飞, 基板加熱をしない ECRPCVD 法による a$\mathrm{Si}: \mathrm{H}$ 膜の赤外吸収スペクトル例12)を示す。

\section{2 局在密度と構造欠陥}

アモルファスシリコンは結晶の上らに長距離秩序や対 称性による強い束縛を受けないために比較的安定に局在 準位が存在でき, 原子間の結合距離, 結合角, 2 面角の 摇らぎを反映して、バンド端はぼけて明確でなくなる。

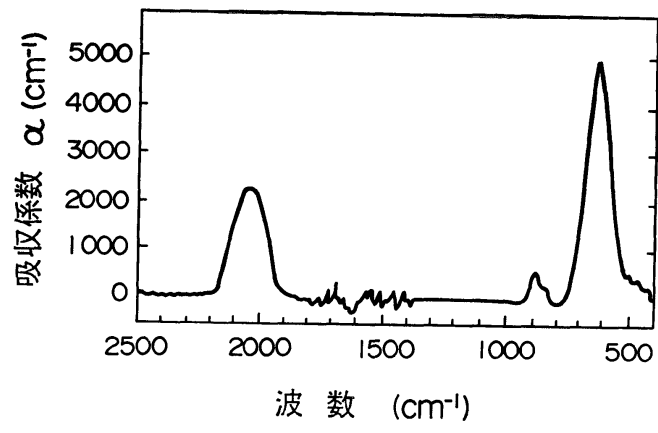

図 1 ECRPCVD 法に上る a-Si:H 膜の赤外吸収 スペクトル例 ${ }^{122}$, (許諾をえて転載(一部修正))

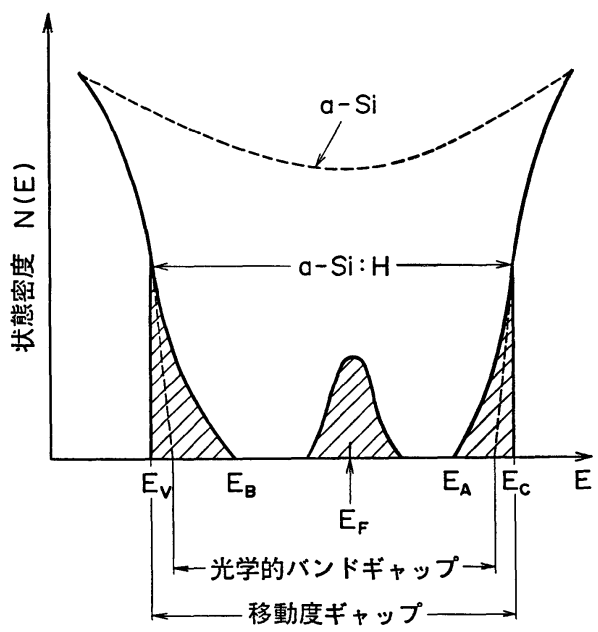

図 2 a-Si:H と a-Si の電子状態密度の概念困

このため, 禁止帯中になだらかな裾を引いた局在電子状 態ができる。これは, テールステーツ (tail states) と呼 ばれている。加光て, 格子欠楩やシリコンのダングリン グボンドによって深い局在準位が生じる。これは, ギャ ップステーツ (gap states) と呼ばれている。

図 2 は, a-Si:H の電子状態密度 $N(\mathrm{E})$ の概念図であ $ろ^{2)}$ 。局在状態の裾は狭く, バンドの中間にダングリン グボンドなどによる局在状態がある。移動度端 $E_{\mathrm{c}}$ と $E_{\mathrm{v}}$ は，局在準位と非局在準位の境界であり， $E_{\mathrm{c}}$ 以上の 状態が結晶の伝導帯 (conduction band) 飞, $E_{\mathrm{v}}$ 以下の 状態が価電子帯 (valence band) に対応している。電気 的なバンドギャップを移動度ギャップ (mobility gap:結 晶でのエネルギーギャップに対応）といい，光学的なギ ヤップを光学的バンドギャップ (optical band gap) と いら。水素を含まない a-Si は高密度の深い局在準位が 存在するため, 光学的バンドギャップは定義できない注 どである。この深い局在準位はドーピングによるフェル ミ準位の移動を妨げ，ドーピング効果や電気伝導に大き な影響を与兄る。従って, a-Si ではドナーやアクセプタ 
となる不純物をドープしても，いわゆる価電子制御がで きない。a-Si:H はこのダングリングボンドを水素が終 端し，バンドギャップ中の局在準位を大きく減少させる ため，例总ば，4配位をとる固換型の燐がドナーとなり， フェルミェネルギーを伝導帯の近傍までシフトさせるこ とが可能になる。Tail states は連続的に分布している 局在準位であり,この電子状態密度は指数関数的に落ち, 光吸収端の指数関数裾を決めている。Tail states の落ち 方は, 価電子帯側に比べ伝導帯側の方が急峻である。物 理的には価電子帯の裾を構成している弱い $\mathrm{Si}-\mathrm{Si}$ ボンド の結合軌道は伝導電子帯の裾の弱い $\mathrm{Si}-\mathrm{Si}$ ボンドの反結 合軌道よりもより局在して抢り, 構造の乱れに影響され やすいためである。その後，弱い $\mathrm{Si}-\mathrm{Si}$ ボンドのほかた tail states 水素も関係していることが解ってきた。結 晶と異なり，a-Si:H そ执いては水素に終端されないで 残るシリコンの電子を 1 個占有して電荷的に中性なダン グリングボンドが単独で存在でき，これは不対スピンを もっているので電子スピン共䳟法 (Electron Spin Resonance：ESR)により観測される。

強い光照射によって暗導電率と光導電率が 共に減少 し, 熱加熱によって回復する光劣化現象：StaeblerWronski 効果が $\mathrm{a}-\mathrm{Si}: \mathrm{H}$ 膜で見い出された ${ }^{13)}$ 。この現象 は結晶シリコンでは見られず，アモルファス特有のもの であり,ダングリングボンドによる欠陥と関係している。

a-Si:H は非平衡状態汹岕るので, 構造欠陥密度は熱 平衡の概念が適用されないと思われてきた。しかし，a$\mathrm{Si}: \mathrm{H}$ に杼いてもダングリングボンド密度やドナーとア クセプター密度は熱平衡過程によって決まるという提案 が 1986 年にされ, 裏づける実験データが出されてい る $^{14), 15)}$ 。

\section{3 運動量保存則の緩和と光学的性質}

アモルファスでは波数 $(k)$ 空間に执いても規則性がな いため光学遷移を起す $k$ 選択則が成立しなくなる。結晶 シリコンのバンドギャップは $1.1 \mathrm{eV}$ と一定值をとり， 光遷移確率は間接遷移型であるため小さい。アモルファ スは $k$ が寿命をもっていると考光られ, あたか子直接遷 移型半導体と類似の吸収端の立ち上がりを示すと考兄ら れている。このため, $\mathrm{a}-\mathrm{Si}: \mathrm{H}$ に就ける光吸収係数は結 晶シリコンより 1 桁以上大きいものが得られ, この性質 は応用上重要となっている。

吸収端のスペクトル形状は, 光吸収係数 $\alpha$ の大きい領 域 $\left(10^{3}<\alpha<10^{5} \mathrm{~cm}^{-1}\right)$ では経験的に光学的バンドギャッ プ $E_{\alpha}$ と光吸収係数 $\alpha$ は,

$$
(\alpha \hbar \omega)^{1 / 2}=B\left(\hbar \omega-E_{\mathrm{g}}\right)
$$

の関係が成立することがわかっている。式 (1) より光学 的バンドギャップは定義されている。B 值は比例定数 で, 光学的バンドギャップと共に大きくなる傾向があ
る。光学的バンドギャップは結晶シリコンの $1.1 \mathrm{eV}$ に 対し, $\mathrm{a}-\mathrm{Si}: \mathrm{H}$ は水素含有量と共に $1.7 \sim 2.0 \mathrm{eV}$ と大き くなる。

\section{4 電気的性質と価電子制御}

アモルファス半導体の直流伝導にはバンド伝導と局在 準位間のホッピング伝導があるが，a-Si:H はダングリ ングボンドターミネータにより局在準位密度が極めて小 さくなり，電気伝導はバンド伝導が支配的となり室温で 活性化型の伝導を示す，すなわち, $\exp \left(-E_{\alpha} / \mathrm{kT}\right)$ と表さ れる。ここで， $E_{a}$ は活性化エネルギーで $E_{a}=E_{C}-E_{F}$ (末たは $E_{F}-E_{V}$ ) である。ドーピングによって,フェル ミ準位が移動度端 $E_{C}$ に近づくにつれ $E_{a}$ は小さくな る。上で無視した局在準位のホッピング伝導としては， 最近接ホッピングと広範围ホッピング（variable range hopping)の 2 種がある。

最近接ホッピングは最近接のドナーサイトにフォノン の吸収や放出を伴って移る電子の運動で, 最近接ドナー サイト間の波動関数の重なりが大きい時にこ起り, 電気 伝導度の温度依存性は活性化型棌なる。

広範囲ホッピング伝導は離れたサイトのエネルギー差 が小さい時, 波動関数の重なりが小さくてもフォノンの 助けをかりてホッピングするものである。ダングリング ボンドに起因する深い準位の伝導や低温での tail states の伝導がこれである。広範囲ホッピング伝導は, $T^{-1 / 4}$ 則 と呼ばれ, $\exp \left(-\right.$ const. $\left./ T^{1 / 4}\right)$ と表される。a-Si:H は, $200 \mathrm{~K}$ 以下の低温では広範囲ホッピング伝導が支配的に なることが知られている。

結晶シリコンに, III 族（例光ばホウ素）又は V 族（例 えば燐) の元素を微量にドープ (dope) すると，それぞ れアクセプタまたはドナー準位が形成できるが，a-Si： $\mathrm{H}$ に対しても同じことが成立することがわかっている。 これは，アモルファスとい党ども化学結合状態関して は結晶と良く似ていることと関係している。 $\mathrm{n}$ 形への制 御は,グロー放電法に护いてホスフィン (phosphine: $\mathrm{PH}_{3}$ ) ガスをシラン (silane: $\mathrm{SiH}_{4}$ ) ガスに混合し，その 混合比でドープ量を制御できる。 p 形はジボラン (dibolane: $\left.\mathrm{B}_{2} \mathrm{H}_{6}\right)$ ガスを $\mathrm{SiH}_{4}$ ガスに混合して得られる。これ により暗導電率は 10 桁程度の変化を示す。ノンドープ の膜の暗導電率は結晶シリコンの $10^{-3} \sim 10^{-4} \mathrm{~S} / \mathrm{cm}$ V対 し $10^{-9} \sim 10^{-10} \mathrm{~S} / \mathrm{cm}$ 之数桁小さいものが得られる ${ }^{7)}$ 。こ の小さな暗導電率はフォトダイオードや薄膜トランジス タなどへの応用に活かされる。a-Si:H 中のドーパント の形としては, 例えば, 燐イオン $\left(\mathrm{P}^{+}\right)$は, そのごく一 部分は 4 配位として組みこま礼るが，残りの大部分は 3 配位になるかあるいはその周囲に新たな欠陥をつくる。 つまり，不純物を入れても置換型ドーパントにならない ものがある。この時, ドーピング効率 クは全燐 $(\mathrm{P})$ 元素 
の密度 $N_{0}$ の $-1 / 2$ 乗に比例する ${ }^{18)}$ 。

\section{5 光電的性質と可視光域光感度}

光電流 $\left(I_{p h}\right)$ は, 光によって生じた自由キャリアが再 結合する前に電極に到達した時に流れる。光励起下での 電流と暗電流の差として,多数キャリアを電子とすると,

$$
\begin{aligned}
I_{p h} & =e \mu E \Delta n \\
& =\eta \mu \tau \cdot e E N_{0}(1-R) \cdot\{1-\exp (-\alpha D)\}
\end{aligned}
$$

と表される。ここで， $\mu$ と $E$ はとれぞれ移動度と電場を 表し， $\Delta n$ は余分に作られたキャリア数である。又，入射 光の単位面積当たりの光子数, $\mathrm{a}-\mathrm{Si}: \mathrm{H}$ の反射率・量子 効率・膜厚をそれぞれ $N_{0}, R, \eta, D$ とする。

図 3 は, p-i 接合型の $\mathrm{a}-\mathrm{Si}: \mathrm{H}$ フォトダイオードの光 感度特性である ${ }^{17)}$ 。光感度のピーク波長は接合構造や膜 厚などによって多少変えることができるが, a-Si:H 膜 の光学的バンドギャップが $1.7 \mathrm{eV}$ 程度のため, 可視光

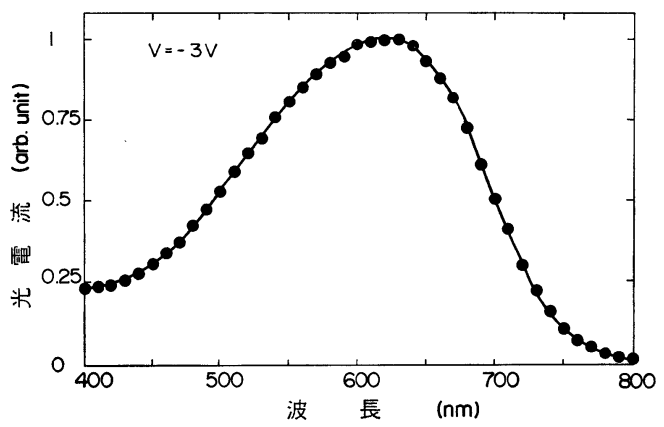

図 $3 \mathrm{p}-\mathrm{i}$ 接合型 $\mathrm{a}-\mathrm{Si}: \mathrm{H}$ フォトダイオードの光感 度特性 ${ }^{17)}$ (許諾をえて転載 (一部修正)

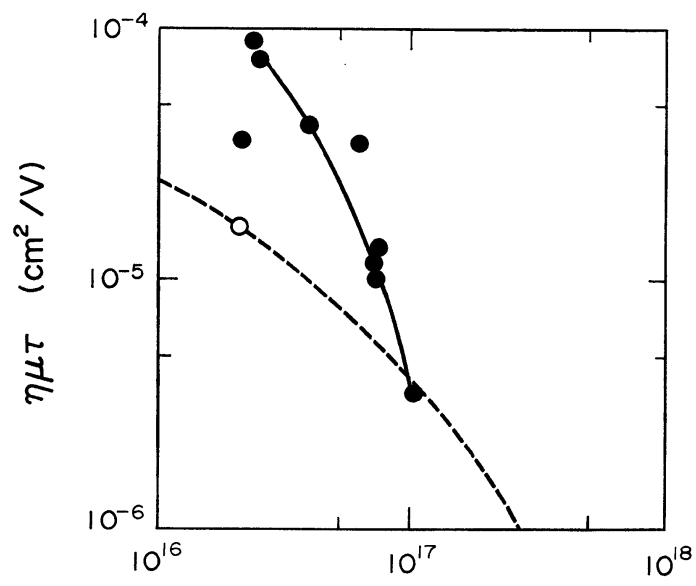

ESR スピン密度 (spins $\left./ \mathrm{cm}^{3}\right)$

図 4 ECRPCVD 法と RFPCVD 法による a-Si: $\mathrm{H}$ 膜に和ける $\eta \mu \tau$ と ESR スピン密度との 関係 ${ }^{21)}$ (許諾を兄て転載（一部修正))

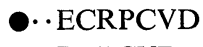

O. RFPCVD
域に光感度をもち, 光センサや太陽電池に応用できる。 長波長側での光感度の減少は, 入射光エネルギーが光学 的バンドギャップより小さくなり, a-Si:H 膜の光吸収 係数が減少するためでもある。短波長側での光感度の減 少は表面近くで吸収される光の量が増加するため, 多数 キャリアである電子の再結合時間に対し電極までの移動 時間が長くなるためでるある。

図 4 は，ECRPCVD 法及び RFPCVD 法による a$\mathrm{Si}: \mathrm{H}$ 膜に抢仔る $\eta \mu \tau$ (式 (2) 参照; 光電的特性の指標, 大きい渒どよい）と ESR スピン密度 $\left(N_{s}\right)$ との相関を見 たものである ${ }^{21)}$ 。ESR スピン密度の減少, つまり,シリ コンの未結合手の減少にともなって $\eta \mu \tau$ は大きくなり, ダングリングボンドが再結合中心として作用しているこ とを示している ${ }^{18)}$ 。 $150 \mathrm{~nm} / \mathrm{min}$ 程度の高速成膜速度に もかかわらず ECRPCVD 法による膜の $\eta \mu \tau$ は, 通常 の RFPCVD 法の基板温度 $250^{\circ} \mathrm{C}$, 成膜速度 $25 \mathrm{~nm} /$ $\min$ の膜に比べ，同じ ESR スピン密度にもかかわらず 大きな光電的特性が得られている。これは後述するよう に,イオンの照射効果によるものである。

\section{3. アモルファスシリコン膜の作製法と前駆体}

アモルファスは非平衡状態であり, 同一素材でも作製 法や作製条件によって状態と性質が異なってくる。例兄 ば，作製法や作製条件によって $\mathrm{a}-\mathrm{Si}: \mathrm{H}$ 膜の局在状態， 水素の結合・組成比が異なり, 電気的・光学的性質が大 きく違ってくる。現在，価電子制御ができるアモルファ ス半導体物質はすべて気相から堆積される方法でしか作 られず，膜状である。

$\mathrm{a}-\mathrm{Si}: \mathrm{H}$ 膜の形成法は 2 つに大別できる。一つはシリ コン原子を含むシラン $\mathrm{SiH}_{4}$ 系のガスをプラズマや光や

表 1 アモルファスシリコンの膜堆積法

1. 化学気相堆積法 (CVD)

（1）グロー放電を主とするもの

(1) DC グロー放電

(2) 誘導結合型グロー放電

(3) 容量結合型グロー放電

(4) ECR 放電

(5) 励起種 CVD

（2）光励起を主とするもの

(1) 直接光分解

(2) 水銀増感光分解

（3）熱分解を主とするもの

(1) 常圧 CVD

(2) 隇庄 CVD

2. 物理気相堆積法 (PVD)

（1）反応性スパッタ法

(2) 蒸着機構を主とするもの

(1) 真空蒸着

(2) イオンクラスタービーム蒸着 
熱などによって分解し膜堆積を行う化学気相堆積法であ り，他はシリコン固体を加熱やスパッタによって膜堆積 を拈こなら物理気相堆積法である。現在のアモルファス シリコンの膜堆積法の種類を表 1 に示す。これらの中で グロー放電法は膜質が良く実用性が最も高いため, 工業 的にはこの方法が用いられている。

グロー放電法の成膜機構は, 次のようなステップが考 えられている。

(1) プラズマによる原料ガスの分解過程

(2) 分解によって生成されたラジカル・イオンの気相 反応・輸送過程

（3）成長表面に和将る表面反応過程

$\mathrm{SiH}_{4}$ のグロー放電法に执いて, 電子との非弾性衝突 によって中性ラジカル種 $\operatorname{SiH}_{x}(x=0 \sim 3)$, イオン種 $\mathrm{SiH}_{x}{ }^{+}(x=0 \sim 3)$ が生成される。中性ラジカル種とイオ ン種の生成比は, 通常の $0.1 \sim 1$ Torr の高周波プラズマ では中性ラジカル種, $10^{-3}$ Torr 以下のプラズマではイ オン種の生成が多くなることが分かっている。基板上に アモルファスシリコンが形成される過程は, 活性種のダ ングリングボンドへの結合，および水素結合への挿入反 応や水素分子の脱離を伴うものが考えられている。

a-Si:H の高品質化のために，通常のグロー放電法に 扣いては前駆体として付着係数が小さい中性ラジカル種 が望ましいと考光られているため，小さな成膜速度しか 期待でさない(19)。このため，高品質化を伴った $\mathrm{a}-\mathrm{Si}: \mathrm{H}$ の堆積速度の向上は 1 つの課題であった。通常のグロー 放電法では，イオン種はシリコン系のダストを発生させ る原因となり，又膜へのイオン衝撃により膜損傷を起こ して膜質を劣化させると考えられた。

そこで，図 5 に示すような気相中での反応を減少する ための低いガス圧力でイオンが多量に生成でき，低運動

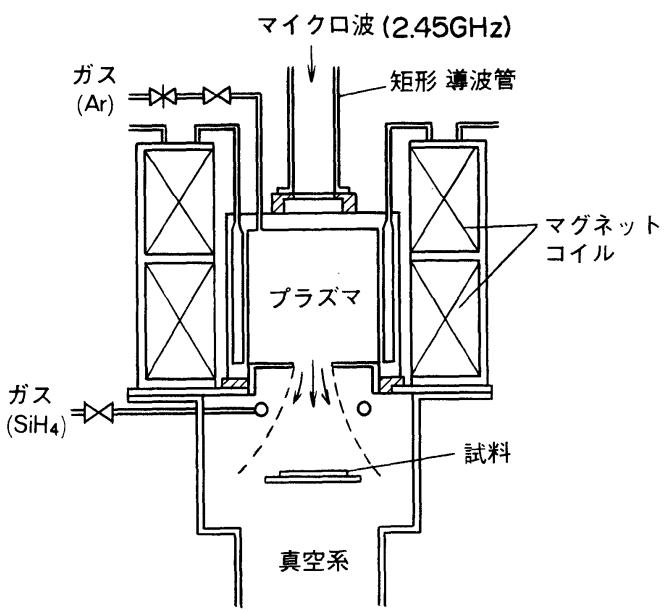

図 5 発散磁場型 ECRPCVD 装置 ${ }^{20)}$ (許諾をえて 転載）

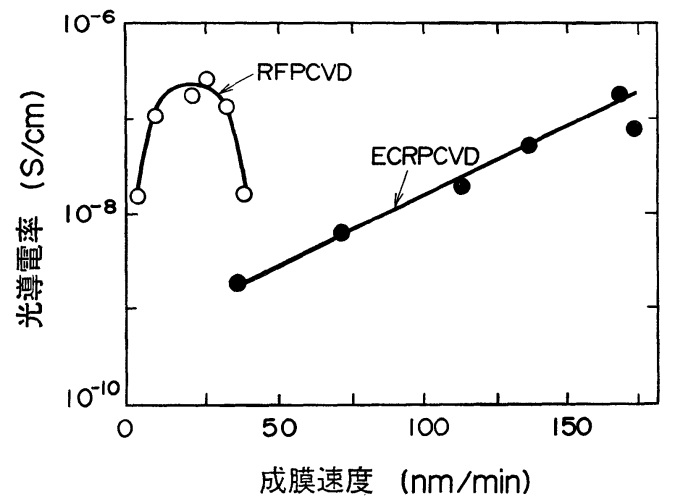

図 6 ECRPCVD 法と RFPCVD 法による a-Si： $\mathrm{H}$ 膜の光導電率と成膜速度との関係 ${ }^{20)}$ (許諾 をえて転載（一部修正））

エネルギーのイオン衝撃が可能な新しい発散磁場型の電 子サイクロトロン共鳴プラズマ化学気相堆積法 (ECRP CVD)を用いて，Hayama 等は $\mathrm{a}-\mathrm{Si}: \mathrm{H}$ 膜を調べ た ${ }^{12), 20), 21)}$ 。

図 6 は, 光導電率 $\left(\sigma_{p h}\right)$ と成膜速度との関係を $\mathrm{ECR}$ CVD 法（基板加熱なし，1 mTorr）による膜と通常の RFPCVD 法 $\left(T_{s}=250^{\circ} \mathrm{C}, 1\right.$ Torr $)$ による膜について比 較したものである ${ }^{20)}$ 。 RFPCVD 法では中性ラジカル種 が優勢であり，せいぜい $40 \sim 50 \mathrm{~nm} / \mathrm{min}$ の成膜速度し か得られず, $30 \mathrm{~nm} / \mathrm{min}$ 以上の成膜速度では光導電率が 低下していく。一方, ECRPCVD 法は RFPCVD 法で は実現不可能であった $170 \mathrm{~nm} / \mathrm{min}$ といら高速成膜速度 を実現し，光導電率は成膜速度と共に大きくなり，大き な光導電率が得られることが示された。これは，ECRP CVD 法では電子とイオンの両方が発散磁場によりプラ ズマチェンバから試料室に効果的に輸送され, 膜表面一 の付着確率が非常に高いシランのイオン種が照射される ことと気相中のポリマーの生成が抑制されるためであ る。この時, ダングリングボンド, 水素含有量, $\left(\mathrm{SiH}_{2}\right)_{n}$ (図 1 参照: $845 \mathrm{~cm}^{-1}$ bending mode), $\mathrm{SiH}_{2}$ (図 1 参照: $2090 \mathrm{~cm}^{-1}$ stretching mode) を減少させるが, $\mathrm{SiH}$ (図 1 参照: $2000 \mathrm{~cm}^{-1}$ stretching mode) は RFPCVD 法よ り多くほとんど一定である浪。つまり, $\mathrm{SiH}_{x}$ のイオン照 射量の増加は成膜速度の増加を起こすと共に，水素引抜 き反応及び水素脱離反応を促進し，ポリシラン相を減少 させ，光導電率を増加させる役割を果たす。又，基板温 度が低い時は，RFPCVD 法も同様に膜中の $\left(\mathrm{SiH}_{2}\right)_{n}$ が 多くなるが，基板加熱なしの ECPCVD 法による膜の $\left(\mathrm{SiH}_{2}\right)_{n}$ は RFPCVD 法での約 $200^{\circ} \mathrm{C}$ の基板温度に対応 し， $\mathrm{SiH}_{x}$ イオン照射による低温化と良好なシリコンネ ットワーク構造の形成が認められている。

このよらに, ECRPCVD 法による a-Si:H 膜の堆積 
そ拈いてはイオン照射効果は低い基板加熱温度と高速成 膜速度を実現し, 大きな光電的特性が得られ, 前駆体と して低ガス圧力で低運動ェネルギーのイオン種が望まし いことがわかってきた。

\section{4. アモルファス半導体の電子デバイスへの応用}

固体電子工学及び電子産業の目覚しい進歩は, シリコ ンテクノロジーを代表とする結晶半導体の技術に支えら れてきたとい光る。これは, 結晶半導体の高純度拈よび 完全結晶化技術, 薄膜形成技術, 微細加工技術等の発展 に基づくものであった。そして, これら技術は電子機器 の高性能化, 高機能化, 小型化, 薄膜化, 省エネルギー 化を推進してきた。しかし，結晶半導体の技術の進歩は 電子機器全体の変革を促進することによって, 他方で,

結晶半導体が不得手な分野での新しい電子デバイスと機 能材料の必要性を顕在化させた。この例として，人間と 機械のインターフェースである画像情報機器, 集積回路 の進歩によっても実現が難しい大容量メモリ, 光応用の 進展によって必要とされる光電子デバイス等が挙げられ る。これらの分野に和いて, 結晶半導体の寸法制限以上 の大面積電子デバイスーの応用, 結晶半導体では一義的 に決定されている光ェネルギー領域の可変化, 可視光に 透明な基板上への膜堆積などの技術開発がなされてい る。

アモルファス半導体の応用の歴史は, 1950年のアモル ファス Se の複写機への応用, 拈よび 1968 年のカルコ ゲナイドガラスのスイッチング素子への応用に始まり，

その後 1973 年のカルコゲナイドガラスの撮像管への応 用を経て，工業的な本格的な応用は 1975 年の価電子制 御可能な $\mathrm{a}-\mathrm{Si}: \mathrm{H}$ の発見から始李った。a-Si:H の応用 は, 1976 年のアモルファスシリコン太陽電池で始まる。 アモルファスシリコン太陽電池 (1980 年), 感光ドラム (1984 年), 密着型イメージセンサ (1985 年), TFT 液晶 テレビ（1987 年）といずれる世界に先駆けて日本に执い て商品化が開始された。

アモルファス半導体材料の大きな応用分野のものを以 下に述べる。

（1） TFT（薄膜トランジスタ）液晶ディスプレイ 液晶ディスプレイの画素のスイッチング素子として a-Si:H 薄膜トランジスタ (Thin Film Transistor: TFT) を用いた a-Si:H TFT-LCD (液晶ディスプレイ) の構 造図を図 7 亿示す 22 。 ガラス基板上に, 低温で大面積の 膜堆積が出来る $\mathrm{a}-\mathrm{Si}: \mathbf{H}$ 膜の特長を活かしたものであ る。薄膜トランジスタのオン電流 $\left(I_{\mathrm{on}}\right)$ は $\sim 10^{-6} \mathrm{~A}$, オ フ電流 $\left(I_{\text {off }}\right)$ は $\sim 10^{-12} \mathrm{~A}$ で, $I_{\text {on }} / I_{\text {off }}$ 比は $\sim 10^{6}$ が得 られている。結晶シリコンに比べてアモルファスなるが 故に, 電界効果移動度 $\left(\mu_{\mathrm{FE}}\right)$ は, $0.1 \sim 1 \mathrm{~cm}^{2} \mathrm{~V}^{-1} \mathrm{~s}^{-1}$ と小

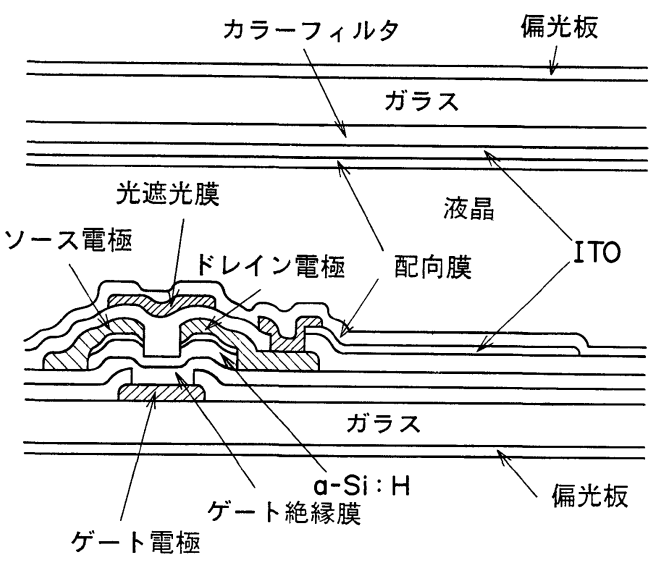

図 7 a-Si:H TFT-LCD の構造例22)（許諾を得て 転載)

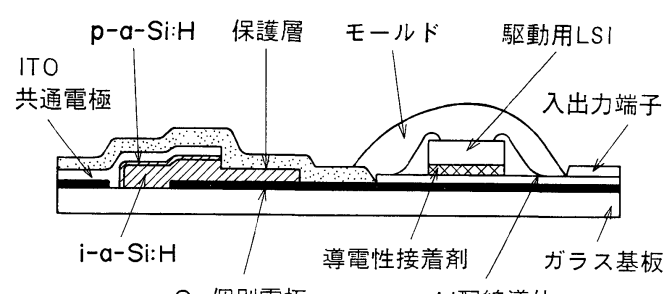

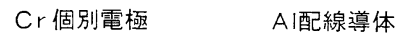

図 8 p-i 接合型 $\mathrm{a}-\mathrm{Si}: \mathrm{H}$ フォトダイオードアレイ を用いた密着型イメージセンサの構造例 ${ }^{17)}$ (許諾を得て転載)

さいが，電圧駆動する液晶表示素子のスイッチング素子 には十分である。

a-Si:H TFT を用いた液晶ディスプレイは，1１4 イ ンチのものができるようになり，TV，ラップトップコ ンピュータ, 車や飛行機用等, 大きな市場が予測されて いる。

(2) イメージセンサ

イメージセンサの小型化をはかるため, 可視光で光感 度をもち大面積化ができる $\mathrm{a}-\mathrm{Si}: \mathrm{H}$ 膜が応用できる。バ ンドギャップが結晶シリコンの $1.1 \mathrm{eV}$ に対し, a-Si:H は $1.6 \sim 1.8 \mathrm{eV}$ であるため, 人間の視感度に近いスペク トル感度を有しているので光センサとして補正する必要 がない。またドーピングしない水素化アモルファスシ リコンは, 結晶シリコンに比べ暗導電率が非常に小さい ので, 素子間の膜の分離を必ずしも必要としないので, 簡単な構造の素子が作製可能になる。

フォトダイオードを一列に並べた密着型イメージセン サは縮小光学系を必要とせず, 小型で軽量であるため, ファクシミリやプリンタ等に応用できる。

図 8 は, p-i 接合型アモルファスンリコンフォトダイ オードを用いた密着型イメージセンサの構造図であ $る^{17)}$ 。光電流は $1 \mathrm{nA}(570 \mathrm{~nm}, 100 \mathrm{~lx})$, 暗電流は $1 \mathrm{pA}$ 
以下で, 明暗電流比は 1000 以上が得られ, 実用上十分 な値である。

(3) 太陽電池

バンドギャップが結晶シリコンの $1.1 \mathrm{eV}$ に対し, 水 素化アモルファスシリコンは $1.6 \sim 1.8 \mathrm{eV}$ であるため, 太陽エネルギーのスペクトルに近い。

a-Si:H 太陽電池が最初に発表された 1976 年の変換 効率は $2.3 \%$ であったが，オイルショックに伴らエネル ギー問題, 公害問題, 宇宙でのエネルギー源などから精 力的に研究開発が行われ, 大面積で $10 \%$ 程度が可能に なってきた。変換効率の向上のために，材料の高品質化 と新構造の研究が行われている。信頼性に执いては, 光 劣化が課題である。

（4）感光ドラム

a-Se を用いて商品化された感光ドラムは, a-Si:H に 移行しつつある。a-SiC:H 料の出現により価電子制御やへテロ接合界面を用いたブ ロック層を持たせて感度を改善し，長寿命で高感度で低 雑音の良い画像コピーができるようになった。膜厚が10 $\mu \mathrm{m}$ 以上と厚いため, 高速の成膜速度と $\mathrm{a}-\mathrm{Si}: \mathrm{H}$ 表面電 荷の非光照射部での保持が課題である。

\section{5. おわりに}

アモルファス半導体の物性とその応用は多くの研究開 発者によって独自の大きな分野に形成されてきたが，末 だ未開拓な領域が残されていると思われる。電子的性質 と電子デバイスへの応用以外にもアモルファスの興味あ る領域があるし，長距離秩序が不要であるため多くの元 素からなる新素材が可能であり，作製技術の進展に伴っ て多成分系の新しいアモルファス材料の出現が今後期待 される。

(1990 年 5 月 21 日受理)

\section{文献}

1) P. W. Anderson: Phys. Rev., 109, 1492 (1958).

2) N. F. Mott \& E. A. Davis: "Electronic Proc- esses in non-crystalline materials", Clarendon Press, Oxford, (1979).

3）菊地 誠監修，田中一宣編：“アモルファス半導 体の基礎”, オーム社, (昭和 57 年).

4) "Semiconductors and Semimetals Vol. 21, "Hydrogenated Amorphous Silicon Part A, B, C and D", ed. by J. I. Pankove, Academic Press, London (1984).

5) 高橋 清, 小長井誠編：「最新アモルファス $\mathrm{Si}$ 八 ンドブック」, サイェンスフォーラム，(1983).

6) "Glow-Discharge Hydrogenated Amorphous Silicon", ed. by K. Tanaka, KTK Scientific Publishers, Tokyo, (1989).

7) W. E. Spear \& P. G. Le Comber: Solid State Commun., 17, 1193 (1975).

8）浜川圭弘：応用物理, 53, 863 (1984).

9）清水 勇: 応用物理, 53, 865 (1984).

10) S. Matuo \& M. Kiuchi: Jpn. J. Appl. Phys., 22, L210 (1983).

11) E. C. Freeman \& W. Paul: Phys. Rev. B18, 4288 (1978).

12) M. Hayama, H. Murai \& K. Kobayashi: $J$. Appl. Phys., 67, 1356 (1990).

13) D. L. Staebler \& C. R. Wronski: Appl. Phys. Lett., 31, 292 (1977).

14) J. Kalalios \& R. A. Street: Phys. Rev., B34, 6014 (1986).

15) Z. E. Smith \& S. Wagner: Phys. Rev. Lett., 59, 688 (1987).

16) R. A. Street: Phys. Rev. Lett., 49, 1187 (1982).

17) M. Hayama: IEEE Tians. Electron Devices, 37, 1271 (1990).

18) R. A. Street: Philos. Mag., B46, 273 (1982).

19) A. Matuda \& K. Tanaka: J. Appl. Phys., 60, 2351 (1986).

20) M. Hayama, K. Kobayashi, S. Kawamoto, H. Miki \& Y. Onishi: J. Non-Crystalline Solids, 97/ 98, 273 (1987).

21) K. Kobayashi, M. Hayama, S. Kawamoto \& H. Miki: Jpn. J. Appl. Phys., 26, 202 (1987).

22) H. Sakamoto, M. Hayama, H. Takasago, T. Sugiura, K. Yamane, H. Arai, Y. Tokutomi, T. Ando, K. Watanabe, H. Miki \& Y. Onishi: Proc. SID., 28/2, 145 (1987). 